\title{
MATADOR TEACHER EDUCATION FOR AFRICA IN THE TWENTY-FIRST CENTURY
}

IDOWU BIAO

\section{ABSTRACT}

Although Africa experienced great educational expansion between 19601983 and although teacher training endeavour knew tremendous expansion during the same period. Africa continues to be plagued by serious social and economic crises. Current analysis shows that political instability begot by corruption, illiteracy, poor health delivery and poverty are the malaises confronting Africa. These malaises would not be eradicated through the educational system and teacher training programme currently run by African countries. The malaises will be eradicated through the work of teachers put through not the current curriculum of teacher education, but a special type of teacher education christened here MATADOR TEACHER EDUCATION. Basically, the matador teacher education programme whose degree and non-degree programmes are here outlined, advocates an eclectic teacher training to carefully selected student teachers. The characteristics that the would-be student teachers of the matador teacher education programme are to possess include a stout psychology, an above average Intelligent Quotient, a fairly healthy physique and a mentality of campaign.

KEY WORDS: Teacher training; Teaching in Africa; Matador teacher; Crisis in teaching; teacher training curriculum.

\section{INTRODUCTION}

Although there has always been in the mind of the pre-independence African educated elite a belief concerning a possible positive correlation between rate of literacy and national development, it was the study of Arnold Smith (1965) that came to strengthen this belief and goad African leaders into taking advantage of this phenomenon. After carrying out some case studies, Smith in 1965, submitted in that famous publication Education and Economic Development, that only countries that are able to raise their literacy level to $\mathbf{4 0}$ percent can hope to start off their societies towards any meaningful economic development.

The period of this publication coincided with the period when most African countries had just been granted political independence. All the independent countries of Africa were at that moment thinking of the quickest ways of bringing social, cultural and economic development to their people. Smith's publication therefore, having strengthened the earlier belief in the mind of the educated Africans, served as a catalyst that goaded African leaders and elites into action towards actualising the continent's development through education.

\section{TREMENDOUS EDUCATIONAL EXPANSION IN AFRICA BETWEEN 1960 AND 1983}

Consequently, African countries with the support of international donor agencies and technical advisers, expanded opportunities for access to modern education. For example, between 1960 and 1983 the number of students enrolled in African institutions at all levels, quintupled (World Bank, 1988:12).

Also,

Primary school enrolments increased the most in absolute terms, growing from approximately 11.9 million pupils in 1960 to 51.3 million pupils in 1983 . The gross primary school enrolment ratio rose from 36 percent to 75 percent over this period (World Bank 1988: 12)

Additionally, the number of teachers increased about fourfold at primary school level, eightfold at secondary school level, and threefold at the tertiary level during this period (World Bank, 1988: 13).

All the studies and findings examined so far belong to the close of the $20^{\text {th }}$ century, since we have just begun the $21^{\text {st }}$ century, a pertinent posture would be to examine the African developmental situation as we begin the $21^{\text {st }}$ 
century. In a pointed manner, we may ask: Has expansion of modem education truly brought about social and economic development in Africa?

The answer is in the negative. Perhaps Africa would have experienced significant development had it enjoyed some measure of political stability.

\section{CORRELATION AMONG EDUCATION DEVELOPMENT AND POLITICAL STABILITY}

African countries which in general gained political independence by 1960 , were all desirous of bringing some form of development to their people. However, no sooner had the colonial masters withdrawn that the factors of ethnicity and greed induced bitter struggles for power among groups of people. In many countries, it was the army, relying on its instruments of mass destruction, that sacked post-independence civilian governments; in other countries, civilian rulers found it convenient to rely on armies they built up to unleash tyranny on defenceless populations; yet in other countries, diarchic governments soon converted the wealth of their nations into private property.

All these distortions brought much tension in the newly independent countries of Africa. Some of the tension actually developed into full-blown civil wars. Although all these social crises began in the mid-1960s, their effects on the social and economic lives of people were magnified only in the 1980s. by mid 1980 s almost all the countries of Africa have come to discover that willy-nilly, they have to find solutions to crushing ecoramic recessions in addition to addressing the effects of wars and social disturbances, natural catastrophes, illiteracy and neglect of preventive medical provision.

\section{Wars and Social Disturbances}

Wars and social disturbances created not only fear and distrust in the mind of people; they also depleted the resources of the newly independent countries. Hugè amounts of money were expended to procure instruments of destruction; many human beings were sent to the battlefield who never returned; all equipment and tools which during time of peace would have been used to promote education and social affairs werfe used to fight social upheavals.

Naturally, these wars and disturbances gave birth to many mentally and physically disabled persons who became a liability unto society. No meaningful and enduring development can take place during periods of war and discord.

\section{Natural Catastrophes}

The two most common natural catastrophes currently known to Africa are droughts and erosion. For a continent whose near total revenue is dependent on agricultural activities, droughts and erosion are truly catastrophes for they rob the continent of means of livelihood. Both subsistence and commercial agricultural practices are hampered. Human development is dependent upon the cooperation of the forces of nature. It therefore follows that no development would take place within a naturally chaotic environment. However, where incidences of natural catastrophes are controlled through a more enlightened behaviour on the part of a more informed educated populate, one could hope for meaningful development.

\section{Illiteracy}

Before 1960, the rate of illiteracy in African countries ranged between 80 to 95 percent (Oyedeji et al, 1982). Four decades after, only Francophone Africa would seem to be comfortably keeping a literacy rate slightly $\mathbf{5 0}$ percent (Biao, 2000; Biao, 1995).

Although prirnary school enrolment received a boost between 1960 and 1980, in the whole of Africa, only 1 out of every 3 school age children is found in school at the close of the $20^{\text {th }}$ century (Biao, 1991).

As a result of econornic recessions, wars and natural catastrophes, many children have been pushed out of school. Many of these children that left school have now grown into adulthood to inflate the initially existing figure of adult illiterates. Yet, literacy is a major catalyst to development.

Health

Malaria (30\%) diarrhoea (20\%) and VPD $(20 \%)$ account for 70 percent of child mortality in Africa; haemorrhage $(23 \%)$, sepsis $(17 \%)$, malaria $(11 \%)$ and anaemia $(11 \%)$ account for about 70 percent of maternal mortality in Africa (UNICEF, 1998).

Since the mid 1990s, malaria and HIVIAIDS have been identified as the tgwo most deadly diseases in Africa. Yet, the truth is that no 
health, ho deverspment sines only healthy persons can work to bring about development.

\section{Poverty}

Although some of African countries are rich in raw materials needed by the developed world, corruption and mismanagement of proceeds made from the sale of such raw materials continue to keep Africar jeopie poor. For example, at the close of the $20^{\text {th }}$ century, 50 percent of African population has been described as being poor while about 19 percent of the population has been described as being extremely poor (UNICEF, 1998). Poverty is debilitating and therefore incapable of promoting development.

These therefore are the social and economic environments of the $21^{\text {st }}$ century Africa within which we intend to conceive of teachers that would be relevant to the continent.

\section{CURRENT APPROACH TO THE TRAINING OF TEACHERS IN AFRICA}

The approach currently employer by all African countries is elitist. It consists at establishing special and separate schools for the training of primary and secondary schools teachers. A few institutes and departments equally exist for the training of teachers of disabled students.

Basically, primary and seccndary schools teachers are trained to equip their eventual students with the skill of literacy (reading. writing and numeracy), general information and in some cases with pre-vocational skills. Facilitators of adult learning help their learners to acquire both traditional and functional literacies and some vocational skills. Special education teachers provide to their students the regular primary and secondary schools curricula contents using their own special techniques of communication.

On the whole therefore, the African teacher is trained to eradicate illiteracy. Yet. illiteracy is not the only malaise the continent is suffering from. Additionally, the world has now abandoned the erroneous view that mere literacy acquisition serves as panacea to all other social problems.

Considering the continent's ills discussed earlier and the current finding, it is clear, the at presently the training of the African teacher is not geared towards solving the daunting problems of the continent. Yet, no other group of workers is better suited for the task of social transformation and social change than teachers

\section{THE TEACHER IN THE EYES OF THE AFRICAN}

In Africa, the teacher is not just a trained individual who operates within the formal or nonformal educational sector. He or she is first and foremost a Very Important Personality (VIP) within his or her community or sphere of influence.

This myth, he/she attracted to himself during the colonial days when the teacher counted among the very few people who could manipulate and function using the language of the master. As a result of his contact with the colonial master, the African teacher did not only come into the possession of uncommon material devices, he is also seen as a person who demonstrates mastery of rare knowledge in almost all areas of human endeavour.

Although between 1960 and now the rate of literacy in Africa has risen from 15 to about 50 percent, and although some military dictators in some African countries had tried to erode the economic power of the teacher, yet, the teacher still commands a fairly high degree of regard in the eyes of both the literate and the illiterate. while the illterate may continue to look upon the teacher with some awe and may be intimidated by the knowledge he is deemed to possess, the literate African elite is aware that the teacher is a veritable change agent that has been used to bring about political, communal and other social changes.

Indeed, if we care to back to periods in history preceding the western colonial period in Africa, we still see that the teacher has always been revered and held in high esteem in Africa.

Within the African traditional apprenticeship system for instance, the teacher is supreme. He is seen as an agent of the god of the particular trade the apprentice is learning; each trade having a god who decides to grant knowledge and dexterity in the said trade in accordance with his assessment of the attitudes of humility, assiduity and reverence with which the learning apprentice approaches his apprenticeship

Fagunwa (1991:55-62) shows the nature of reverence which the apprentice demonstrates towards his teacher when he says: 
Oh! My master, my good master. who made me what I am today through the indigenous apprenticeship. I cannot forget you My master, I respect you for all that I have learnt from you. I have learnt more than anybody can see. I have acquired from you more than technical knowledge and skill.................have acquired loyalty to master and craft concentration of mind, personal discipline, struggle for achievement..................Again. my master, let me thank you for making me what l am today.

Islamic teachers were the earliest type of "colonial masters" that visited Africa. They were said to have arrived in Africa as early as the $11^{\text {th }}$ century AD. While they traded with the people. they taught them Arabic and the content of the Qu'uran. "Mu'alim" or "Mu'alimah" is the word for teacher in Arabic. At the hearing of this word, all heads bow in reverence and respect, this is because the "mu'alim" or "mu'alimah" is one who obeyed the Prophet's injunction that even if the site where to obtain knowledge be as far as China, the student should do all in his or her powers to reach the place. The Prophet's injunction lays emphasis on knowledge acquisition and the "mu'alim" is respected because of the knowledge he is deemed to possess. More importantly however, the "mu'alim" is revered because it is generally believed that the type of knowledge be possesses is one that is useful to society, it is a type of knowledge that can save society from perdition

\section{THE CONCEPT OF MATADOR TEACHER}

A matador according to Oxford Diction is "a performer whose task is to fight and kit the bull in a bullfight". The premise upon which the concept of matador teacher is based in the present discussion is that. considering the enormous ability possessed by the teacher to bring about social transformation, he is is ine person best suited to be used as instrument to confront and eradicate the daunting socia! and economic problems facing Africa.

This type of teacher not existing before now. must now be created through training. The ills currently afflicting Africa being so multifarious and so formidable. the teacher that must help in their eradication must equally be eclectically prepared, he must equally be stout in his determination to carry out teaching in an environment so uncomfortable

Specifically. the following are the characteristics which the matador teacher must be possessed with.

Psychology

The matador teacher shall be trained in the psychology of the different major groups of students that are currently identified on the continent These major types of students include young learners also referred to as formal education students. adult learners also known as non-formal education learners and special education clients also known as disabled students

Unlike the present practice where three different persons are trained in each of these aspects of teacher education. only one person shall be trained in theses three teacher education aspects

More importantly. the personal psychology of the matador teacher shall be bult up in a way that is not currently done. The idea shall be built into him that is not "teaching profession" but a "teaching campaign". that is. while his training is on he shall be brought to realise that he is trained to wage war through teaching against the ills earlier on discussed which if not eliminated within the quickest possible time may grow to snuff life out of everyone

Within the psyche of the matador teacher, shall also be buit up a sense of stout determination and fortitude to confront the challenged of eradicating the identified ills

\section{Mental Disposition}

The work awaiting the matador teacher is a Herculean one not only in a physical sense but also in a mental sense. Consequently. those that are to be selected for training under their programme would have to exhibit an above average Intelligent Quotient (I Q.)

During and after his training. his mental flexibility should be such that a matador teacher can function among young able-bodied learners in a moment and in the next moment he is working among disabled students. he should be able to leave disabled students to begin work with adult learners 


\section{Physique}

By necessity, the physical fitness of the matador teacher must be medically proved to be above average since much physical demand may be imposed on him in the course of the discharge of his duties.

\section{Eclectic Curriculum}

The training programme of the matador teacher shall be built around the pieces of knowledge now available to us in the disciplines of Pedagogy, Andragogy and Special Education.

Two levels of training are here recommended: first a non-degree teacher training programme and secondly a degree teacher training programme.

\section{Non-Degree Programme}

1) Principles of Pedagogy, Andragogy and Special Education

2) History of Pedagogy, Andragogy and Special Education

3) Organisation of Pedagogy; Andragogy and Special Education

4) Monitoring and Evaluation of Pedagogy, Andragogy and Special Education Programmes.

5) Practical work in Pedagogy, Andragogy and Special Education

6) Principles and Practice of Extension Services

7) Literacy Studies

8) Peace Education

9) Income Generating Activities

10) Moral and Civic Education

Two full calendar (not academic) years of study after 4 or 5 years of secondary school education shall be required for the non-degree programme. This is because much needs to be covered as outlined on the list of relevant courses. The holders of the non-degree programme certificate are expected to teach in primary schools.

The first group of five courses on that list concerns general and broad training in the fields of Pedagogy Andragogy and Special Education. The second group of five courses concerns specific training that is needed to eradicate or control the six major problems currently afflicting the continent.

For example, the principles and practice of extension services course is designed to inform the teacher and through him, the African populace about methods and techniques of beneficial and harmless health knowledge, attitudes and practices and agricultural behaviours and practices. Literacy studies course would equip the teacher with the right methods and techniques for bringing about literacy. Peace Education course would inform the teacher and through him the African populace of techniques of conflict resolution and methods of sustaining peace at communal and global levels. Income generating activities studies are designed to equip the teacher and through him the African populations with skills in generating income in modern economy. Moral and civic education course would check corruption and immorality among teachers and African populations.

It is expected that the course on Principles of Pedagogy. Andragogy and Special Education in addition to other things, would train the student teacher in the methods of teaching the official language of the country, Mathematics, Social Studies and Integrated Sciences.

\section{Degree Programme}

1) History of Pedagogy, Andragogy and Special Education

2) Psychology of Pedagogy, Andragogy and Special Education

3) Sociology of Pedagogy, Andragogy and Special Education

4) Methods and Techniques of Pedagogy, Andragogy and Special Education

5) Management in Pedagogy, Andragogy and Special Education.

6) Monitoring and Evaluation of Pedagogy, Andragogy and. Special Education programmes.

7) Practical work in Pedagogy. Andragogy and Special Education.

8) Principles and Practice of Extension Services

9) Literacy Studies.

10) Peace Education

1.1) Income Generating Activities

12) Moral and Civic Education

Four full calendar (not academic) years of study after 4 or 5 years of secondary school education shall be required for the Degree programme. The graduates of this programme are to teach in secondary schools. The first group of seven courses constitute the general and broad knowledge needed in the fields of Pedagogy, Andragogy and Special Education The other five 
cour4ses are meant to address the specific continental issues discussed earlier.

It is expected that the course on Methods and Techniques in addition torother things, would train the student teacher in methods of teaching the official language of the country, Mathematics and other science and social subjects.

\section{TRAINING STRATEGIES}

The facilities presently in place for teacher training would need to alter significantly. There should now be only one type of teacher training school from where matador primary school teachers and secondary school teachers would be trained

Specialists in the tree disciplines are to come to instruct in the matador teacher training schools These specialists can currently be found in tertiary institutions Specialists in Andragogical sciences and Special Education are fewer indeed compared to specialists in Pedagogical sciences. In order therefore to make a success of the training of matador teachers, many teacher training schools should be established in areas not too distant from tertiary institutions

\section{MATADOR TEACHER AND CLASS STRUGGLE}

All societies including African societies exist in strata or social classes. Under cover struggle does go on unabated between these different social classes and teachers are not insulated from these class struggles. Between the colonial period and now, the prestige of the African teacher has deteriorated indeed. In this beginning of the $21^{\text {st }}$ ceritury, the African teacher may be said to be in the lowest rung of the middle class

The matador teacher is not expected to immediately quit this social class upon completion of the first batch of trainees However. since the matador teacher is one person of strong psychology and of above average Intelligence Quotient, it is expected that members of this new colony of teachers will in time infiltrate other strata of society from where initiatives aimed at keeping the matador teacher in the appropriate social stratum, may be launched One cardinal factor that may guide the matador teacher in launching himself unto the appropriate social class would be the relevance and actual field results of his performance during the initial years of the training of this new corps of teachers

\section{ADVANTAGES OF MATADOR TEACHER TRAINING}

This type of teacher training pivgramme is first and foremost cost effective in that it significantly reduces the cost involved in establishing two separate structures for the training of primary and secondary school teachers. Secondly, it is useful and relevant because it is designed to address the problems of the teachers' milieux. Thirdly. it tends to make available more teachers than we now have. Fourthly, the teachers would enjoy high morale because their relevance to their milieux would be self-evident. Fifthly, the matador teacher would give a broader knowledge of teaching than the present teachers possess

\section{CONCLUSION}

African social and economic crises are daunting. Teachers have been identified as reliable helpers in the process of resolving these crises. However, it will be further helpful in African nations would seek the support of international organisations in promoting and implementing the matador teacher education strategy for crises resolution.

\section{REFERENCES}

Biao, 1., 2002. "Non-formal basic education in Francophone and Anglophone Africa" in Umoren. G. Ntia, U. N. \& Biao, I. (2002) (eds) Readings in Adult Education. Calabar: Department of Adult \& Continuing Education, University of Calabar

Biao, 1. 1995. Acomparatice sturdy of adult literacy education practices in Francophone and Anglophone West Africa" Internatıonal Journal of University Adult Education. XXXIV, 2 44-55

Biao, I, 1991. "Towards a political commitment approach to the provision of education for all in Nigeria" in Kolo, I. et al. (eds) Readings in education for all. Lagos: Text \& Leisure Publishers.

Fagunwa. D . 1991. "Oh! My master. an appraisal of indigenous apprenticeship in lle-lfe. Nigeria" Adult Education and Development 36. 55-63. 
Hawkins, J. M.; 1983. The Oxford paperback Dictionary $2^{\text {nd }}$ Edition.

Oyedeji, L. et al, 1982. A handbook of literacy education for West Africa. Ikeja: Longman.

UNICEF, 1998. CSPD: Key social statistics in Africa. UNICEF
Smith, A., 1965. "Literacy and schooling in the development threshold: some historical cases." in Smith, A.et al (1965) Education and economic development Chicago: Longman

World Bank, 1988. Education in Sub-Saharan Africa. Washington D.C. World Bank. 